\title{
Correction to: The Values of Receptor Activator Nuclear Kappa-B Ligand Expression in Stage III Giant Cell Tumor of the Bone
}

\author{
Sabrina Abdul Ghani ${ }^{1} \cdot$ Wan Faisham Wan Ismail ${ }^{1} \cdot$ Md. Salzihan Md. Salleh $^{2} \cdot$ Sahran Yahaya $^{1}$. \\ Muhamad Syahrul Fitri Zawawi ${ }^{1}$
}

Published online: 17 September 2021

(c) Indian Orthopaedics Association 2021

\section{Correction to: \\ Indian Journal of Orthopaedics (2018) 52: 31 \\ https://doi.org/10.4103/ortho.IJOrtho_153_17}

The original version of this article unfortunately contained a mistake. The first names and last name of the author Muhamad Syahrul Fitri Zawawi were tagged incorrectly.

The original article can be found online at https://doi.org/10.4103/ ortho.IJOrtho_153_17.

\section{Wan Faisham Wan Ismail}

faisham@usm.my

1 Department of Orthopaedics, School of Medical Science, Universiti Sains Malaysia, 16150 Kubang Kerian, Kelantan, Malaysia

2 Department of Pathology, School of Medical Science, Universiti Sains Malaysia, 16150 Kubang Kerian, Kelantan, Malaysia 